Article

\title{
Towards Development of a Label for Zero Emission Buildings: A Tool to Evaluate Potential Zero Emission Buildings
}

\author{
Devi Bühler ${ }^{1}$, Thorsten Schuetze ${ }^{2}$ and Ranka Junge ${ }^{3, *}$
}

1 Synergy Village, Oberschirmensee 16, 8714 Feldbach, Switzerland; E-Mail: devi@synergy-village.org

2 Department of Architecture, Sungkyunkwan University, 2066 Seobu-ro Jangan-gu, Suwon-si, Gyeonggi-do 440-746, Korea; E-Mail: t.schuetze@skku.edu

3 Institute for Natural Resource Sciences, ZHAW Zurich University of Applied Sciences, 8820 Waedenswil, Switzerland

* Author to whom correspondence should be addressed; E-Mail: jura@zhaw.ch; Tel.: +41-58-934-5922; Fax: +41-58-934-5911.

Academic Editor: Marc A. Rosen

Received: 14 January 2015 / Accepted: 15 April 2015 / Published: 27 April 2015

\begin{abstract}
The operation of so-called Zero Emission Buildings (ZEB) does not result in harmful emissions to water, soil and air. In contrast, ZEBs produce energy, water and resources. Therefore, the definition of ZEBs in this paper goes well beyond the definition of (Net) Zero Energy Buildings, which focuses primarily on greenhouse gas emissions resulting from the combustion of fossil fuels. The concept of ZEB is based on the decentralization of urban infrastructure systems on the building level. The aim is to avoid environmental impacts during the building operation through sustainable production, management, consumption, and recycling of resources. In order to facilitate an easy evaluation of ZEBs a ZEB assessment tool needed to be developed. This paper discusses the development of the general framework, the assessment method, and the ZEB Assessment Tool (ZEBAT), which facilitates the evaluation of the environmental performance of potential ZEBs. The exemplary evaluation of selected case studies from Switzerland and South Korea illustrates the method and the practicability of the ZEBAT for the evaluation of potential ZEBs. The holistic integration of environmental performance factors and their specific environmental impacts facilitates the successful application of the ZEBAT independently from the specific use of a building and its geographical location.
\end{abstract}


Keywords: Zero Emission Buildings; evaluation tool; case studies; Switzerland;

South Korea; decentralization; sustainable technologies; infrastructure systems

\section{Introduction}

Worldwide, many building certification systems are available in order to promote the design, planning and construction of sustainable buildings. Examples for such sustainable building certification systems, which have been considered in the framework of this research are: MINERGIE (Mehr Lebensqualität, tiefer Energieverbrauch ("Higher living quality, lower energy consumption", developed in Switzerland) [1], DGNB (Deutsche Gesellschaft für nachhaltiges Bauen, "German Association for Sustainable Building", developed in Germany) [2], HQE (Haute Qualité Environnementale, "High environmental quality" developed in France) [3], BREEAM (Building Research Establishment's Energy Assessment Method, developed in the United Kingdom) [4], LEED (Leadership in Energy and Environmental Design, developed in the United States of America) [5], and CASBEE (Comprehensive Assessment System for Building Environmental Efficiency, developed in Japan) [6].

In addition to the listed sustainable building certification systems, many more systems are available. The available evaluation and certification system are either one-dimensional, focusing on the evaluation of cumulative energy demand, or are multi-dimensional, focusing on total quality assessment and/or life cycle assessment [7].

However, the direct and indirect emissions to soil, water and air during the operation of a building during its lifetime are generally not assessed or only to a limited degree. The DGNB system [2], for example, which aims to be one of the most comprehensive sustainable certification systems worldwide, includes the Life Cycle Analysis of the building itself in the certification of buildings. The operation and management of the resource flows of water and biomass are only considered to a very limited degree. Furthermore, the application of existing sustainable building certification systems such as the DGNB is very complex, because the system aims to support the integrated design and planning of sustainable buildings. Generally such certified buildings are connected to conventional urban infrastructure systems and aim for significant reduction of environmental impacts by increased efficiency.

In addition to the conventional approach of Sustainable and Net Zero Energy Buildings [8,9], the concept of Zero Emission Buildings (ZEB) discussed in this paper addresses emissions from energy and material (biomass, water) flows, which result from the operation of buildings. Accordingly ZEBs do not produce harmful emissions but produce energy, water and resources. This ZEB concept envisions maximum decentralization of urban infrastructures on building and property levels. The aim is the decentralized and building integrated sustainable production, management, consumption and recycling of energy, water, and the reduction of environmental impacts during the operation to the greatest possible degree [10,11]. Most evaluation tools for the issue of an Energy Performance Certification (EPC) such as the Swiss Building Energy Certification of the Cantons (Gebäudeenergieausweis der Kantone-GEAK) [2] or the German Energy Saving Ordinance (EnergieEinsparVerordnung-EnEV) [12] address solely energy aspects during the operation of buildings. Therefore the definition of ZEBs in 
this paper goes well beyond the definition of (Net) Zero Energy Buildings, which focuses primarily on greenhouse gas emissions resulting from the combustion of fossil fuels $[8,9,13,14]$.

In order to facilitate a comparable fast and easy evaluation of potential ZEBs, according to the three sectors Energy, Water and Biomass, a ZEB assessment tool was developed $[15,16]$ in the framework of the ZEB-ISTIS (Zero Emission Building-Integrating Sustainable Technologies and Infrastructure Systems) research project [17]. The subsequent sections of this paper discuss the development of the general framework, the assessment method, and the ZEB Assessment Tool (ZEBAT), which facilitates the evaluation of the environmental performance of potential ZEBs. The primary goal of this study was therefore the development of ZEBAT without in depth validation. Nevertheless, the exemplary evaluation of selected case studies from Switzerland and South Korea illustrates the method, and the practicability of the ZEBAT for the evaluation of potential ZEBs. The holistic integration of environmental performance factors and their specific environmental impacts facilitate the successful application of the ZEBAT independently from the specific use of a building and its geographical location.

\section{Methods}

\subsection{Requirements and Considerations}

The development of a tool to evaluate potential Zero Emission Buildings had to be well adapted to the requirements of the ZEB concept, based on the definition of Schuetze et al. [10]. These requirements are: suitable for the evaluation of existing buildings (find case studies), assessment of the three Sectors Energy, Water, Biomass as well as qualitative aspects, applicable to different countries and locations, and the incorporation of various environmental impacts, such as emissions to air, water and soil, consumption of resources and production of wastes.

The evaluation of the three Sectors Energy, Water and Biomass was a crucial element for the development of the tool. The respective Sectors were defined as all processes and technologies implemented in building construction and operation related to (i) energy aspects, such as energy efficiency and renewable energy generation; (ii) water aspects, such as wastewater treatment and technologies for water efficiency; and (iii) biomass aspects, such as nutrient recovery and composting.

For the development of the ZEB Assessment Tool (ZEBAT), six specific decision parameters (Pre-Assessment, System boundary, Quantification of environmental impact, Database, Qualitative aspects, Calculation of target value) were compiled in order to be specified in a further step (Figure 1).

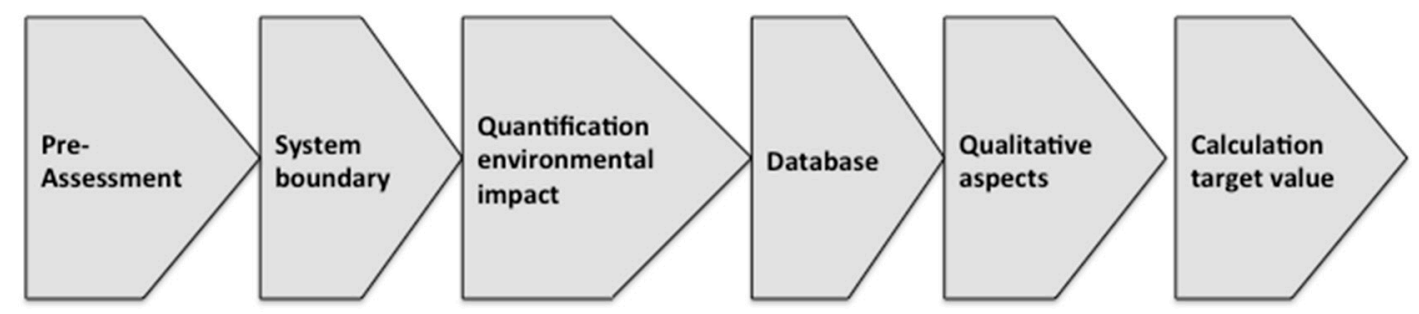

Figure 1. Decision parameters for the development of the Zero Emission Buildings Assessment Tool (ZEBAT). 
Each of the six different decision parameters demanded different requirements based on the requirements of the ZEB concept. The considerations for the decision parameters, in order to appoint an appropriate characteristic to them, are listed in Table 1. Each of the specific parameters is discussed in detail in the subsequent Sections 2.2.1-2.2.6.

Table 1. Considerations of decision parameters for the development of the ZEB Assessment Tool.

\begin{tabular}{ll}
\hline \multicolumn{1}{c}{ Decision Parameter } & \multicolumn{1}{c}{ Considerations } \\
Pre-Assessment & $\begin{array}{l}\text { How can a pre-assessment be easily conducted in order to determine if the } \\
\text { building is eligible for a further examination with the tool? } \\
\text { What method can be applied to ensure the building address the three sectors } \\
\text { to a minimum level? }\end{array}$ \\
\hline System boundary & $\begin{array}{l}\text { What processes should be considered? } \\
\text { Which processes have an environmental impact? }\end{array}$ \\
\hline Quantification of & How and with what method can the environmental impact be quantified? \\
\hline Database & Which method fulfils the requirements of the ZEB concept? \\
\hline \multirow{3}{*}{ Qualitative aspects } & Which databases can be used to look up the values for the relevant flows? \\
& $\begin{array}{l}\text { How can qualitative aspects be assessed in a quantitative way? } \\
\text { Which criteria should be considered? }\end{array}$ \\
\hline \multirow{3}{*}{ Calculation of target value } & How can sensible benchmarks be established? \\
& $\begin{array}{l}\text { How can consideration be given to different building purposes and } \\
\text { corresponding variation of resource consumption? } \\
\text { How should the target value be calculated and expressed? }\end{array}$ \\
\hline
\end{tabular}

\subsection{Development of ZEB Assessment Tool}

The ZEBAT discussed in this paper was developed based on Microsoft Excel, because it is a very widely used program, which can generally be easily operated by many users. The six decision parameters and basic considerations, which are summarized in Table 1 have been taken as a starting basis for the development of the Microsoft Excel based ZEBAT. Specific characteristics, indicators, and assessment criteria were identified and assigned to each of the six decision parameters. These are described in the subsequent Sections 2.2.1-2.2.6.

\subsubsection{Pre-Assessment: Eligible Technologies}

The decision parameter pre-assessment evaluates whether a building fulfils the minimum requirements of the ZEB concept and is thus eligible for further assessment as a potential ZEB. A simple questionnaire evaluates whether the building sufficiently addresses the three sectors Water, Energy and Biomass. For each sector a list of so-called "eligible technologies", which target efficient use of resources and energy, was compiled (Table 2). A building received a "fulfilled" for one sector if it implemented at least two of the eligible processes/technologies of the corresponding sector. As a next requirement of the Pre-Assessment, the building had to fulfil at least two of the named sectors. If a building passed the Pre-Assessment it was further investigated with the ZEBAT in order to quantify and benchmark the environmental performance. The Pre-Assessment ensures the integrity of the concept up to a certain level. For instance, if a building solely implemented water saving devices, it 
would be inappropriate to state that the building appropriately addresses the aspect of water within the ZEB concept.

Table 2. Eligible technologies for the assessment of the three sectors of the Zero Emission Building (ZEB) Concept. At least two sectors with at least two technologies each should be implemented in a building in order to qualify for further evaluation.

\begin{tabular}{cl}
\hline Sector & \multicolumn{1}{c}{ Eligible technologies } \\
\hline Water & $\begin{array}{l}\text { Rainwater harvesting, water saving devices, decentralized wastewater treatment, water } \\
\text { re-use, urine separation }\end{array}$ \\
\hline \multirow{2}{*}{ Energy } & $\begin{array}{l}\text { Photovoltaic, solar thermal collectors, wind turbine, geothermal energy, highly insulated } \\
\text { envelope, heat recovery, use of waste heat, passive energy use }\end{array}$ \\
\hline \multirow{2}{*}{ Biomass } & $\begin{array}{l}\text { Composting of organic waste, composting of feces, vermicomposting, nutrients recovery } \\
\text { from urine, production of fertile soil, biochar production, food production on site (soil based } \\
\text { or soilless, such as hydroponic, aquaponics), biomass production on site }\end{array}$ \\
\hline
\end{tabular}

\subsubsection{System Boundary: Site Boundary}

The decision parameter system boundary is an essential aspect regarding the analysis of the resource consumption of specific buildings. The site boundary was taken as the system boundary with the additional requirement that the considered flows had to be conveyed by human activity. As a result, solely flows into and out of the site, which involved human activity, were considered, such as grid electricity and fresh water supply. Consequently, on-site resource management, such as renewable energy generation, e.g., with photovoltaic, or the collection of rainwater, while being considered for the Pre-Assessment, were not further quantified since they do not have an environmental impact during their operation and automatically result in less grid electricity use or freshwater use respectively. The relevant energy and resource flows in the energy and water sector are grid electricity consumption (Grid electricity), consumption of external energy sources (External energy), consumption of freshwater from central supply facility (Freshwater), and discharge of wastewater into a central treatment plant (Wastewater). The notation provided in brackets will hereinafter be used when referring to the corresponding energy or resource flow.

A visualization of the system boundary and the relevant energy and resource flows is shown in Figure 2.

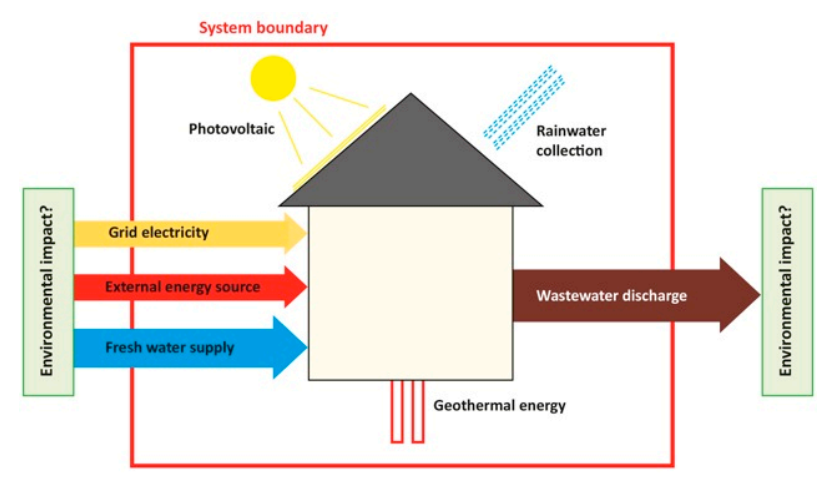

Figure 2. System boundary and relevant flows for the ZEB Assessment Tool. Only resource and energy flows into and out of the system boundary and that are conveyed by human activity are taken into consideration. 
The Biomass sector has fundamentally different characteristics from the Energy and Water sectors and therefore could not be described using the concept of the above resource flows. The considerations for the assessment of sector Biomass are described in Section 2.2.3.

\subsubsection{Quantification of Environmental Impact: Ecological Scarcity}

The decision parameter environmental impact aims for the quantification of the previously described relevant energy and resource flows in a measurable unit. The selected quantification is based on the so-called "ecological scarcity method" which has the advantage that it incorporates multiple environmental impacts and takes into account different countries of location. In contrast, using the global warming potential as a method would neglect such aspects as water scarcity. In detail, the ecological scarcity method [18] covers the following environmental impacts: Emissions to air, surface waters, groundwater, and soil, consumption of resources, and production of wastes.

The ecological scarcity method is a "distance to target" based method. The environmental impacts, as listed above, are weighted with "eco-factors". These eco-factors are derived from environmental laws or political targets. The output is expressed in Umweltbelastungspunkte" (UBP: German for "environmental pollution points", also known as Eco-points) per unit of pollutant emission or resource extraction [18]. The calculation of an eco-factor is based on three steps: Characterization, Normalization and Weighting. The step of Weighting is based on the corresponding political targets that define a critical annual flow in the reference area. Frischknecht et al. [18] defined the calculation for the eco-factor for every environmental impact as follows:

$$
\text { Eco-factor }=K \cdot \frac{1 \cdot E P}{F_{n}} \cdot\left(\frac{F}{F_{k}}\right)^{2} \cdot c
$$

In Equation (1) $K$ denotes Characterization factor of a pollutant or of a resource, $F_{n}$ Normalization flow (current annual flow, with Switzerland as system boundary), $F$ is Current annual flow in the reference area), $F_{k}$ denotes Critical annual flow in the reference area, $c$ is constant $\left(10^{12} / \mathrm{a}\right)$. The unit of assessed result is expressed in Eco-points $(E P)$ [18].

The UBPs for all environmental impacts of a specific resource flow are summed up resulting in a total number of UBP. This number of UBP was used for the ZEBAT to quantify the environmental impact of the relevant resource flows as described in Section 2.2.2. In practice, the number of UBP refers to the environmental impact that the considered flow causes. Thus, if a building has a high number of UBP, it can be derived that it has a higher environmental impact than a building with a lower UBP value. Conclusively, a building with zero UBP is a true ZEB.

\subsubsection{Database: KBOB, Ecoinvent Database, Own Calculations}

The required UBP values for the ZEBAT were taken from different databases. The "Koordinationskonferenz der Bau- und Liegenschaftsorgane der öffentlichen Bauherren" (KBOB) is an organization that makes recommendations for sustainable building and publishes specialized life cycle assessment data for the building industry in the so-called KBOB-List [19]. The available datasets in the KBOB-list were used for the ZEBAT. The datasets in the KBOB-List are based on datasets of the Ecoinvent Database [20]. The remaining datasets were taken directly from the Ecoinvent Version 3 
Database, which is one of the most comprehensive international databases for Life Cycle Inventory data [20]. Due to its comprehensiveness, Ecoinvent was able to provide most of the remaining datasets for the tool.

The used datasets for the Water and Energy sectors are listed in Tables 3 and 4 respectively. As mentioned previously, the evaluation of the Biomass sector necessitated a different approach than the Water and Energy sectors. The input of biomass into the system occurs in the form of food, feces or urine. It is difficult to determine what environmental impact these inputs have. For example, it is difficult to determine the UBP value for one kilogram of feces if it is unclear where the food came from and where the feces are disposed. Even if it were possible to calculate a UBP value, the input of feces could not be avoided like for example grid electricity consumption. The solution was not to calculate the UBP value for the input, but to calculate how much UBP could be avoided if a specific process was applied. For example, if nutrients were recovered from urine, this would avoid the need for a specific amount of fertilizer bought on the market. The UBP value for fertilizer could easily be looked up in the Ecoinvent database. All the datasets and calculations for the Biomass sector are described in Table 5. The input of biomass also depends on the number of persons. The values for the biomass flows are also listed in Table 5.

\subsubsection{Qualitative Aspects: Additional Points}

The ZEB Assessment Tool also provides "malus points" if important qualitative aspects of a building construction were not taken into consideration. Currently, no database exists for these aspects thus a set of criteria were established based on inputs by experts of the corresponding field $[21,22]$. The survey resulted in six criteria (Table 6). 
Table 3. Data sources for the sector Water in the Zero Emission Buildings Assessment Tool (ZEBAT).

\begin{tabular}{|c|c|c|c|}
\hline Parameter & Value & Source & Dataset/Calculation \\
\hline Freshwater & $\mathrm{UBP} / \mathrm{m}^{3}$ & & \\
\hline Germany & 1366.3 & Calculation & $\begin{array}{l}\text { Eco-factor for freshwater D: } 910 \mathrm{UBP} / \mathrm{m}^{3} \text { [18] } \\
\text { Distribution of water: } 338 \mathrm{UBP} / \mathrm{m}^{3} \text { (based on Ecoinvent: Tap water, at user } / R E R U \text { [23]) } \\
\text { Losses through distribution: } 1.13 \mathrm{~m}^{3} / \mathrm{m}^{3} \text { (based on Ecoinvent: Tap water, at user } / R E R U \text { [23]) } \\
910 \times 1.13+338=1366.3 \mathrm{UBP} / \mathrm{m}^{3}\end{array}$ \\
\hline South-Korea & 484.9 & Calculation & $\begin{array}{l}\text { Eco-factor for freshwater KR: } 130 \mathrm{UBP} / \mathrm{m}^{3}[18] \\
\text { Distribution of water: } 338 \mathrm{UBP} / \mathrm{m}^{3} \text { (based on Ecoinvent: Tap water, at user } / R E R U \text { [23]) } \\
\text { Losses through distribution: } 1.13 \mathrm{~m}^{3} / \mathrm{m}^{3} \text { (based on Ecoinvent: Tap water, at user } / R E R U \text { [23]) } \\
130 \times 1.13+338=484.9 \mathrm{UBP} / \mathrm{m}^{3}\end{array}$ \\
\hline Turkey & 677 & Calculation & $\begin{array}{l}\text { Eco-factor for freshwater TR: } 300 \mathrm{UBP} / \mathrm{m}^{3}[18] \\
\text { Distribution of water: } 338 \mathrm{UBP} / \mathrm{m}^{3} \text { (based on Ecoinvent: Tap water, at user } / R E R U[18] \text { ) } \\
\text { Losses through distribution: } 1.13 \mathrm{~m}^{3} / \mathrm{m}^{3} \text { (based on Ecoinvent: Tap water, at user } / R E R U \text { [23]) } \\
300 \times 1.13+338=677 \mathrm{UBP} / \mathrm{m}^{3}\end{array}$ \\
\hline Switzerland & 4077.2 & Ecoinvent & treatment of wastewater, average, capacity 5E9l/year, CH, (Author: Roland Hischier active) * \\
\hline Germany & 4158.2 & Ecoinvent & treatment of wastewater, average, capacity 5E9l/year, RoW, (Author: [System] inactive)* \\
\hline South-Korea & 4158.2 & Ecoinvent & treatment of wastewater, average, capacity 5E9l/year, RoW, (Author: [System] inactive) * \\
\hline Turkey & 4158.2 & Ecoinvent & treatment of wastewater, average, capacity 5E9l/year, RoW, (Author: [System] inactive) * \\
\hline
\end{tabular}


Table 4. Data sources for the sector Energy in the Zero Emission Buildings Assessment Tool (ZEBAT).

\begin{tabular}{|c|c|c|c|}
\hline Parameter & Value & Source & Dataset/Calculation \\
\hline Grid electricity & $\mathrm{UBP} / \mathrm{kWh}$ & & \\
\hline CH Grid electricity & 412.68 & Ecoinvent & market for electricity, low voltage, $\mathrm{CH},($ Author: Karin Treyer active) $*$ \\
\hline $\mathrm{CH}$ Label-certified electricity & 50.618 & Ecoinvent & market for electricity, low voltage, label-certified, CH, (Author: Karin Treyer active) \\
\hline DE Grid electricity & 685.14 & Ecoinvent & market for electricity, low voltage, DE, (Author: Karin Treyer active) \\
\hline DE Label-certified electricity & 50.618 & Ecoinvent & market for electricity, low voltage, label-certified, CH, (Author: Karin Treyer active) \\
\hline KR Grid electricity & 626.28 & Ecoinvent & market for electricity, low voltage, KR, (Author: Karin Treyer active) \\
\hline TR Grid electricity & 1592.7 & Ecoinvent & market for electricity, low voltage, TR, (Author: Karin Treyer active) \\
\hline External Energy & UBP/MJ & & \\
\hline Heating oil & 44.4 & KBOB & Energie-Brennstoffe-Heizöl EL, ID-Nummer: 41.001 \\
\hline Natural gas & 31.5 & KBOB & Energie-Brennstoffe-Erdgas, ID-Nummer: 41.002 \\
\hline Fire wood, logs & 27.6 & KBOB & Energie-Brennstoffe-Stückholz, ID-Nummer: 41.006 \\
\hline Wood chips & 27.1 & KBOB & Energie-Brennstoffe-Holzschnitzel, ID-Nummer: 41.00 \\
\hline Pellets & 27.8 & KBOB & Energie-Brennstoffe-Pellets, ID-Nummer: 41.008 \\
\hline Biogas & 30.4 & KBOB & Energie-Brennstoffe-Biogas, ID-Nummer: 41.009 \\
\hline District heating & 24.2 & KBOB & Energie-Fernwärme-Fernwärme mit Nutzung Kehrichtwärme, Durchn. Netze CH, ID-Nummer: 42.017 \\
\hline Rape-seed oil & 15.51 & Simapro ** & Calculation with Simapro [23] \\
\hline
\end{tabular}

* The notations in italics stand for the full name of the dataset in the corresponding database (Ecoinvent or KBOB). The Ecoinvent data can be found on [20];

** Simapro is a specialized software to calculate Life Cycle Inventory data. 
Table 5. Data sources for the sector Biomass in the Zero Emission Buildings Assessment Tool (ZEBAT).

\begin{tabular}{|c|c|c|c|}
\hline Parameter & Value & Source & Dataset/Calculation \\
\hline \multicolumn{4}{|l|}{ Biomass flows: } \\
\hline Urine per person (L/d) & 1.4 & [24] & \\
\hline Feces per person $(\mathrm{kg} / \mathrm{d})$ & 0.14 & [24] & \\
\hline Organic kitchen waste per p. ( $\mathrm{kg} / \mathrm{a})$ & 150 & [25] & \\
\hline \multicolumn{4}{|l|}{ Biomass processes: } \\
\hline $\begin{array}{l}\text { Composting of feces } \\
\text { (avoided UBP/kg feces) }\end{array}$ & 12.8 & Calculation & $\begin{array}{l}\text { Ecoinvent (EI): market for compost, GLO, (Author: [System] inactive) *: } 51.261 \mathrm{UBP} / \mathrm{kg} \\
\text { portion dry matter of feces: } 0.25[26] \\
51.261 \times 0.25=12.8 \mathrm{UBP} / \mathrm{kg} \text { feces }\end{array}$ \\
\hline $\begin{array}{l}\mathrm{N} \text { recycling from urine for fertilizer } \\
\text { (avoided UBP/L urine) }\end{array}$ & 412.5 & Calculation & $\begin{array}{l}\text { EI: market for nitrogen fertilizer, as } N, \text { GLO, (Author: [System] inactive): } 10,985 \mathrm{UBP} / \mathrm{kg} \\
\mathrm{N} \text { concentration in urine: } 9.2 \mathrm{~kg} / \mathrm{m}^{3}[27] \\
\mathrm{N} \text { concentration in fertilizer: } \varnothing 24.5 \%[28] \\
10,985 / 0.245 \times 9.2 / 1000=412.5 \mathrm{UBP} / \mathrm{L} \text { urine }\end{array}$ \\
\hline $\begin{array}{l}\text { P recycling from urine for fertilizer } \\
\text { (avoided UBP/L urine) }\end{array}$ & 23.8 & Calculation & $\begin{array}{l}\text { EI: market for phosphate fertilizer, as P2O5, GLO, (Author: [System] inactive): } 10,131 \mathrm{UBP} / \mathrm{kg} \\
\text { P concentration in urine: } 0.54 \mathrm{~kg} / \mathrm{m}^{3}[27] \\
\text { P concentration in fertilizer: } \varnothing 23 \%[28] \\
10,131 / 0.23 \times 0.54 / 1000=23.8 \mathrm{UBP} / \mathrm{L} \text { urine }\end{array}$ \\
\hline $\begin{array}{l}\text { Nutrients recovery of organic } \\
\text { kitchen waste } \\
\text { (avoided UBP } / \mathrm{kg} \text { waste) }\end{array}$ & 10.25 & Calculation & $\begin{array}{l}\text { EI: market for compost, GLO, (Author: [System] inactive): } 51.261 \mathrm{UBP} / \mathrm{kg} \\
\text { portion dry matter of organic kitchen waste: } 0.2[29] \\
51.261 \times 0.2=10.25 \mathrm{UBP} / \mathrm{kg}\end{array}$ \\
\hline
\end{tabular}

* The notations in italics stand for the full name of the dataset in the corresponding database (Ecoinvent [20] or KBOB [19]). 
Table 6. Compilation of criteria for the evaluation of qualitative aspects.

\begin{tabular}{|c|c|c|c|c|}
\hline & Criteria & Fully applies & Partially applies & Does not apply \\
\hline & Additional Points & +0 Points & +800 Points & +1600 Points \\
\hline 1 & Good connection to public transport & $\begin{array}{l}\text { Public traffic } \\
\text { connection } \\
\text { within } 300 \mathrm{~m}\end{array}$ & $\begin{array}{l}\text { Public traffic } \\
\text { connection within } \\
1 \mathrm{~km}\end{array}$ & $\begin{array}{c}\text { Public traffic } \\
\text { connection over } \\
1 \mathrm{~km} \\
\end{array}$ \\
\hline 2 & Integration of greenery into the building & $\begin{array}{c}\text { Roof and façade } \\
\text { greening }\end{array}$ & $\begin{array}{l}\text { Roof or façade } \\
\text { greening }\end{array}$ & No greening \\
\hline 3 & $\begin{array}{l}\text { Building construction is suitable for a potential } \\
\text { change of use: } \\
\text { Suitable location: change of use is legally } \\
\text { permitted according to zoning plan; } \\
\text { Suitable building shape: compact cubic shapes } \\
\text { are more suitable for potential change of } \\
\text { use [21] }\end{array}$ & $\begin{array}{c}\text { Suitable } \\
\text { location and } \\
\text { building shape }\end{array}$ & $\begin{array}{l}\text { Suitable location } \\
\text { or building shape }\end{array}$ & None of both \\
\hline 4 & $\begin{array}{l}\text { Building is constructed from ecological } \\
\text { materials, i.e. recycled materials or readily } \\
\text { available primary raw materials [30] }\end{array}$ & $80 \%-100 \%$ & $40 \%-80 \%$ & $0 \%-40 \%$ \\
\hline 5 & $\begin{array}{l}\text { Grey energy of construction } \\
\text { (per energy reference area, } 60 \text { years lifetime; } \\
\text { according to bulletin SIA } 2032 \text { [31] }\end{array}$ & $<30 \mathrm{kWh} / \mathrm{m}^{2} \mathrm{a}$ & $30-60 \mathrm{kWh} / \mathrm{m}^{2} \mathrm{a}$ & $>60 \mathrm{kWh} / \mathrm{m}^{2} \mathrm{a}$ \\
\hline 6 & $\begin{array}{l}\text { Building design fits into the surrounding } \\
\text { environment and urban framework: } \\
\text { this is a qualitative and somewhat subjective } \\
\text { criterion, therefore not easily measurable. It } \\
\text { requires solid knowledge of the place and its } \\
\text { history. General criteria are: shape, size, } \\
\text { proportions, color, and materials. Since each } \\
\text { site is unique each architectural answer will } \\
\text { differ [21]. }\end{array}$ & $\begin{array}{l}\text { Adapted shape } \\
\text { and materials }\end{array}$ & $\begin{array}{c}\text { Adapted shape or } \\
\text { materials }\end{array}$ & None of both \\
\hline
\end{tabular}

The assessment of a criterion is based on the allocation of one of the three grades "Fully applies", "Partially applies" and "Does not apply". The benchmarks for the allocation of the grades were established using different methodologies. Criterion 1 fully applies if the connection to public transport is directly located at the site and accessible within no more than $10 \mathrm{~min}$. The benchmark was set at $300 \mathrm{~m}$ walking distance. The benchmark between "Partially applies" and "Does not apply" was set at one kilometer since this is still a reasonable distance for walking, however many people might choose another means of transport. The benchmarks for criteria 2, 3 and 6 were established by choosing two possible options in order to fulfil the criterion. If both options were applied, the building received a "Fully applies". If only one option was implemented, the building was graded as "Partially applies". If none of the two options were implemented, the building was graded as "Does not apply". For criteria 4 and 5, the benchmark values were aligned with benchmark values in the literature such as Minergie [32] or the references in Table 6.

Dependent on fulfilment of these criteria, additional points were added to the environmental performance of the object: Zero points for "Fully applies", 800 points for "Partially applies" and 
1600 points for "Does not apply". These values were established based on data from examined case studies since to date there is no comparable data in the literature. After the assessment of the three sectors Energy, Water and Biomass, the examined buildings achieved an average "Rating Points per $\mathrm{m}^{2}$ " of 9600 . Consequently, the maximal value for additional points was set as 9600 , which means that the building has a very bad performance in terms of qualitative aspects. This value ensures that the qualitative aspects are weighted equitably with the quantitative aspects. All criteria and benchmarks are compiled in Table 6.

\subsubsection{Calculation of Target Value: Building Types, Benchmarks, Degree of Achievement}

As an output value for the tool, it was decided to calculate a degree of achievement based on the achieved Rating Points of the assessed building. The achieved number of Rating Points for the assessed object was calculated as follows:

$$
\text { Achieved Rating points }=\frac{U B P_{\text {Water }}+U B P_{\text {Energy }}+U B P_{\text {Biomass }}}{\text { Area }}+\text { Additional UBP }
$$

Subsequently, the degree of achievement was calculated:

$$
\text { Degree of achievement }(\%)=100-\frac{100 \times \text { Achieved } U B P}{\text { Benchmark }}
$$

If a building achieved at least $80 \%$, it was granted the "Zero Emission Building Label". To set this benchmark was a compromise with the actual objective of ZEB, which envisions zero environmental impact thus zero UBP. However, if this goal has been applied, presumably no building would have reached the ZEB Label. The benchmark of $80 \%$ allowed for some environmental impact but still ensured an outstanding environmental performance.

To what extent a specific building reaches a target value largely depends on the building's purpose since this significantly adds to the consumption of resources for the building's operation. Therefore the classification into building types with different allocated benchmarks was essential. The parameter Benchmark in Equation (3) changes according to the building purpose. The different benchmarks were established as follows: In the first step, a basic benchmark was established based on experimental data from different case study buildings examined with the ZEBAT. If these buildings did not incorporate any of the eligible technologies as listed in Table 2 then they would not qualify as ZEB and would have achieved less than $80 \%$ degree of achievement. Several such buildings obtained typical values of around 100,000 Rating Points for zero degree of achievement. Thus, the 100,000 value was taken as a starting value. For the ZEBAT, the energy consumption indicator of Minergie was converted into a general consumption index, which is proportionally in line with the energy consumption indicator of Minergie. The chosen classification corresponds to the classification of Minergie [32]. Minergie calculates for every building a weighted energy consumption indicator in matters of end energy. The indicator is expressed in $\mathrm{kWh} / \mathrm{m}^{2}$ and is a crucial benchmark for the Minergie label. The energy consumption indicator varies for the different types of buildings. Subsequently, the benchmark for each building type was calculated from the consumption index where Index 1 corresponds to 100,000 Rating Points. This benchmark value therefore corresponds to zero degree of achievement. The classification of building types, the Minergie energy consumption indicators, and the benchmarks for ZEBs are listed in Table 7. 
Table 7. Classification of buildings with benchmarks based on the energy consumption indicator of Minergie [1]. The benchmark value corresponds to zero degree of achievement for the particular type of building.

\begin{tabular}{|c|c|c|c|}
\hline Building type & $\begin{array}{c}\text { Minergie energy consumption } \\
\text { indicator }\left(\mathrm{kWh} / \mathrm{m}^{2}\right)\end{array}$ & $\begin{array}{c}\text { Consumption } \\
\text { Index }\end{array}$ & $\begin{array}{c}\text { Benchmark } \\
\text { (Rating Points) } \\
\end{array}$ \\
\hline Industry Store & 20 & 1 & $100,000 *$ \\
\hline Sport installation & 25 & 1.25 & 125,000 \\
\hline $\begin{array}{l}\text { Apartment building } \\
\text { Single-family Home }\end{array}$ & 38 & 1.9 & 190,000 \\
\hline $\begin{array}{l}\text { Administration Sales } \\
\text { School Meeting venue } \\
\text { Special construction }\end{array}$ & 40 & 2 & 200,000 \\
\hline Restaurant/Hotel & 45 & 2.25 & 225,000 \\
\hline Hospital & 70 & 3.5 & 350,000 \\
\hline
\end{tabular}

* The 100,000 Rating Points benchmark represents the basic benchmark for the Zero Emission Buildings Assessment Tool (ZEBAT). It was established based on experimental data of buildings examined with the ZEBAT.

\section{Results and Discussion}

\subsection{ZEB Assessment Tool}

The required input parameters for the assessment of a potential Zero Emission Building by using the ZEBAT are listed in Table 8.

Table 8. Input parameters and units for the ZEBAT.

\begin{tabular}{ll}
\hline Input parameter & Unit or Description \\
\hline Country & - \\
\hline Building type & - \\
\hline Total effective area of building & $\mathrm{m}^{2}$ \\
\hline Average occupancy per day & $\mathrm{Number}$ of people \\
\hline Freshwater & $\mathrm{m}^{3} / \mathrm{a}$ \\
Wastewater & $\mathrm{m}^{3} / \mathrm{a}$ \\
\hline Grid electricity & $\mathrm{kWh} / \mathrm{a}$ \\
Electricity product & - \\
External energy & $\mathrm{MJ} / \mathrm{a}$ \\
\hline Application of: & \\
-Composting of feces & YES/NO \\
-N recycling from urine for fertilizer & YES/NO \\
-P recycling from urine for fertilizer & YES/NO \\
-Nutrients recovery from organic kitchen waste & YES/NO \\
\hline -Good connection to public transport & FA/PA/NA \\
-Integration of greenery into the building & FA/PA/NA \\
-Construction is suitable for a potential change of use & FA/PA/NA \\
-Building is constructed from ecological materials & FA/PA/NA \\
-Grey energy of construction & FA/PA/NA \\
-Building design fits into the surrounding environment & FA/PA/NA \\
\hline
\end{tabular}

* Units FA, PA and NA denote "fully applies", "partially applies" and "does not apply", respectively. 
The implementation of the ZEBAT in Microsoft Excel is illustrated in Figures 3-6. Figure 3 shows the Pre-Assessment where the implemented technologies can be selected from the list of eligible technologies. The Tool automatically evaluates if the building is eligible for further assessment based on the defined conditions in Section 2.2.1 Pre-Assessment.

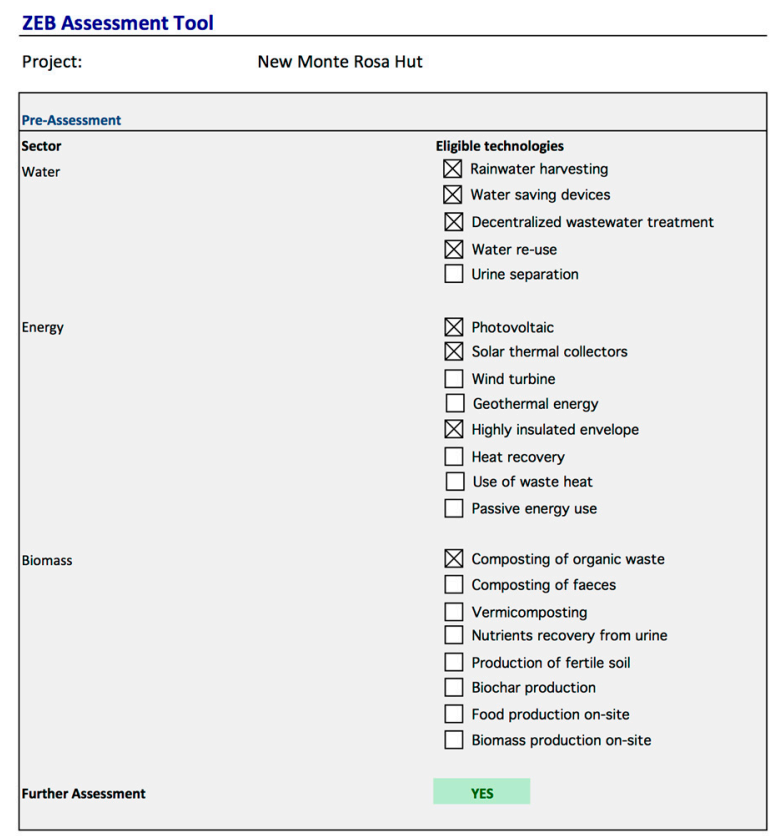

Figure 3. Pre-Assessment in the ZEB Assessment Tool. Buildings qualify for further assessment if they implement at least two of the eligible processes/technologies in at least two of the named sectors.

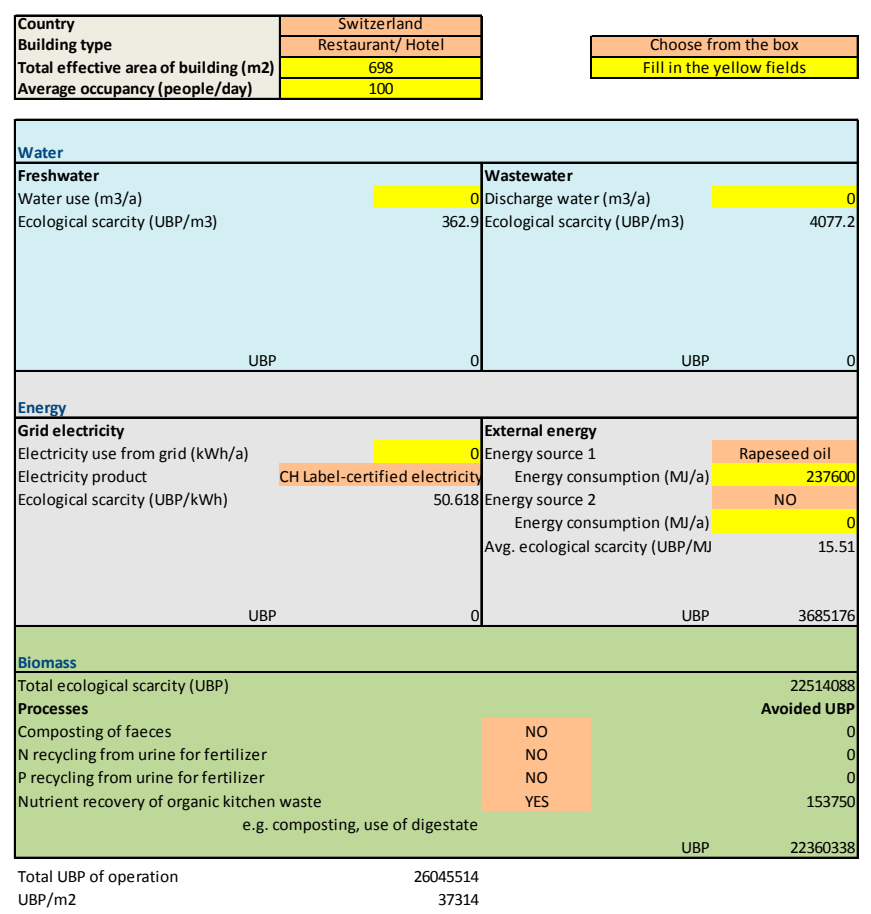

Figure 4. Example of assessment of the three sectors Water, Energy and Biomass in the Zero Emission Buildings Assessment Tool (ZEBAT). 
Figure 4 shows the assessment of the three sectors Energy, Water and Biomass. The user has to select certain values from a box and fill in the required values for the resource and energy flows.

Figure 5 illustrates the evaluation of qualitative aspects. The user has to select to what degree the corresponding criterion applies.

\begin{tabular}{|c|c|c|c|}
\hline \multirow{5}{*}{$\begin{array}{l}\text { Good connection to public transport } \\
\text { Integration of greenery into the building } \\
\text { Building construction is suitable for a potential change of use } \\
\text { Building is constructed from ecological materials }\end{array}$} & Fully applies & \multicolumn{2}{|c|}{ Partially applies Does not apply } \\
\hline & 0 & 0 & 0 \\
\hline & 0 & 0 & O \\
\hline & 0 & 0 & 0 \\
\hline & 0 & 0 & 0 \\
\hline \multirow{3}{*}{$\begin{array}{l}\text { Grey energy of construction } \\
\text { Building design fits into the surrounding environment }\end{array}$} & 0 & 0 & 0 \\
\hline & 0 & (c) & 0 \\
\hline & \multicolumn{2}{|r|}{ Additional UBP } & 4800 \\
\hline
\end{tabular}

Figure 5. Example of the assessment of qualitative aspects in the Zero Emission Buildings Assessment Tool (ZEBAT).

Figure 6 shows the output data of the tool and to what degree the assessed building complies with the ZEB concept. The graphics illustrate to what degree the parts of the assessment are responsible for the output, in order to indicate the potential for further improvement of the building.

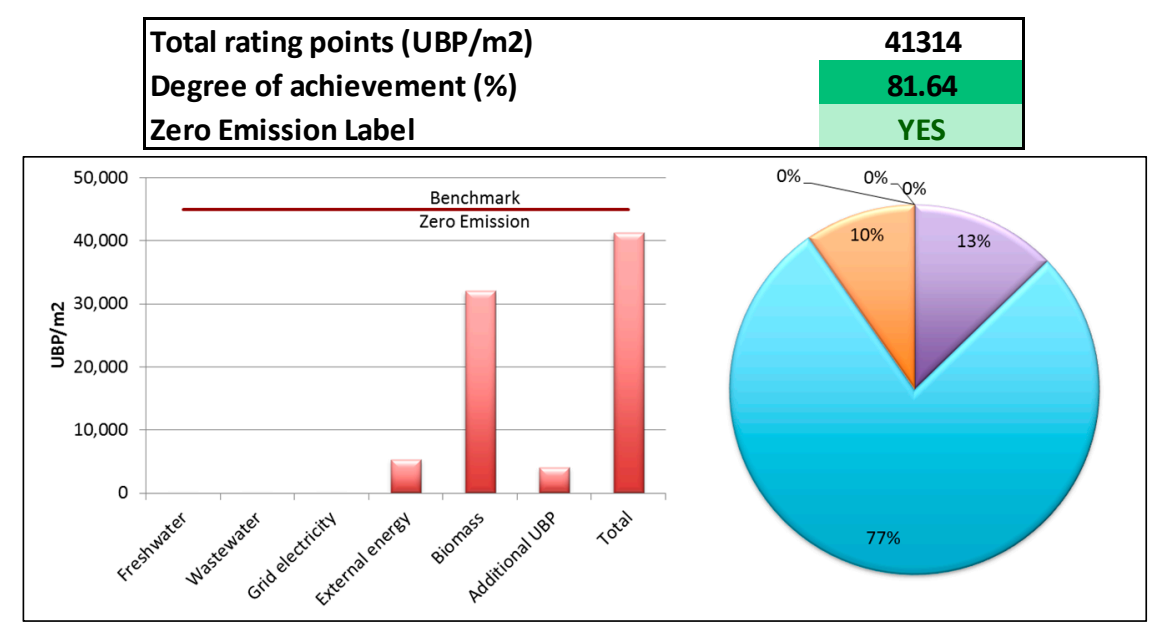

Figure 6. Example of the output of the Zero Emission Buildings Assessment Tool (ZEBAT).

\subsection{Application of ZEB-Tool on Case Studies from Switzerland and South Korea}

The ZEB Assessment Method was used to evaluate potential ZEBs in Switzerland and Korea.

A total of 17 buildings from Switzerland and one from Korea that were constructed under the consideration of sustainable building were assessed with the ZEBAT (Table 9). Only 5 of these qualified for further evaluation after the Pre-Assessment. This was because most of them considered only one sector, and the tool requires fulfilment of at least two sectors. The characteristics of buildings that were examined further are listed in Table 10. 
Table 9. Evaluation of some sustainable buildings in Switzerland and one case study from South Korea. Fulfilled sectors are marked with $x$. The shaded buildings qualified for further evaluation with the ZEB Assessment Tool due to the integration of "eligible technologies" concerning energy and material flows.

\begin{tabular}{lccc}
\hline \multicolumn{1}{c}{ Building Name } & \multicolumn{2}{c}{ Sector } \\
\hline Apartment building, Minergie-A-Eco, 9030 Abtwil & Energy & Water & Biomass \\
Apartment building, Minergie-A-Eco, 3415 Rüegsauschachen & $\mathrm{x}$ & & \\
Aquamin, single-family home, 4528 Zuchwil & $\mathrm{x}$ & $\mathrm{x}$ & $\mathrm{x}$ \\
Credit Suisse administration building, 8036 Zürich & $\mathrm{x}$ & & \\
Forum Chriesbach, administration building Eawag, 8600 Dübendorf & $\mathrm{x}$ & $\mathrm{x}$ & $\mathrm{x}$ \\
Hotel Muottas Muragl, 7503 Samedan & $\mathrm{x}$ & & $\mathrm{x}$ \\
Kantonsbibliothek Liestal & & & \\
Mountain station Hohtälli, Zermatt & & $\mathrm{x}$ & \\
New Monte Rosa Hut, Hotel & $\mathrm{x}$ & $\mathrm{x}$ & \\
Schollglas AG Insulation factory, 3940 Steg & $\mathrm{x}$ & & \\
Single-family home, Minergie-A-Eco, 3700 Spiez & $\mathrm{x}$ & & \\
Single-family home, Minergie-A-Eco, 7530 Zernez & $\mathrm{x}$ & & \\
Single-family home, Minergie-A-Eco, 3800 Matten b. Interlaken & $\mathrm{x}$ & & \\
Single-family home, Minergie-A-Eco, 3204 Rosshäusern & $\mathrm{x}$ & \\
Single-family home, Minergie-A-Eco, 3186 Dündigen & $\mathrm{x}$ & & \\
Solar-Restaurant Klein Matterhorn, 3920 Zermatt & $\mathrm{x}$ & & \\
Umwelt Arena, Meeting venue, 8957 Spreitenbach & $\mathrm{x}$ & $\mathrm{x}$ & \\
Kolon e+ Green Home, South Korea & $\mathrm{x}$ & $\mathrm{x}$ & \\
\hline
\end{tabular}

The comparison of the five buildings (Figure 7) shows that Forum Chriesbach reaches the highest degree of achievement, which is therefore the best practice example so far of Zero Emission Buildings in Switzerland and Korea. Its main strength is that it addresses all three sectors (Energy, Water and Biomass) to a significant degree. In particular, the Biomass sector is much further developed in comparison to the other case studies investigated in the framework of this thesis. However, the technologies applied for the resource management in the Biomass sector are all still at pilot study level and not yet suitable for a broader application. This also reveals the need for more research on such technologies in order to broaden the complete concept of ZEB. The Korean Kolon e+ Green Home achieves the lowest end energy demand per $\mathrm{m}^{2}$ and person per year (Figure 7). It is the only case study that achieves energy autonomy on a yearly basis and does not use any external energy sources excluding electricity. Furthermore, the building has low electricity consumption per $\mathrm{m}^{2}$ and person per year.

Nevertheless, from Table 10, it can be seen that each case study achieved at least one best value for an indicator. Thus, each case study demonstrates an outstanding performance in a specific area. The findings from these specific areas serve as valuable sources for the further development of ZEBs. The ultimate goal is to combine these insights into future ZEBs. 
Table 10. Comparison of case studies which qualified for further evaluation with the ZEB Assessment Tool after the Pre-Assessment (see also Table 9).

\begin{tabular}{|c|c|c|c|c|c|c|}
\hline Indicator & Unit & Umwelt Arena & $\begin{array}{c}\text { Forum } \\
\text { Chriesbach }\end{array}$ & $\begin{array}{c}\text { New Monte Rosa } \\
\text { Hut }\end{array}$ & $\begin{array}{c}\text { Aquamin } \\
\text { Zuchwil }\end{array}$ & $\begin{array}{c}\text { Kolon e+ Green } \\
\text { Home }\end{array}$ \\
\hline Country & - & Switzerland & Switzerland & Switzerland & Switzerland & South-Korea \\
\hline Source & - & {$[33]$} & [34-36] & {$[37,38]$} & {$[1,15,39]$} & {$[40]$} \\
\hline Building type & - & Meeting venue & Administration & Restaurant/ Hotel & $\begin{array}{l}\text { Single-family } \\
\text { Home }\end{array}$ & $\begin{array}{l}\text { Single-family } \\
\text { Home }\end{array}$ \\
\hline Total effective area & $\mathrm{m}^{2}$ & 10,000 & 5012 & 698 & 251 & 295 \\
\hline Average occupancy per day & number of persons & 400 & 240 & 100 & 4 & 4 \\
\hline \multirow{2}{*}{$\begin{array}{l}\text { Fresh water use from central } \\
\text { supply facility }\end{array}$} & $\mathrm{m}^{3} /$ person & 6 & 7 & 0 & 23 & 90 \\
\hline & $\mathrm{m}^{3} / \mathrm{m}^{2}$ area & 0.25 & 0.33 & 0 & 0.36 & 1.21 \\
\hline \multirow{2}{*}{$\begin{array}{c}\text { Wastewater discharge into } \\
\text { central treatment plant }\end{array}$} & $\mathrm{m}^{3} /$ person & 9 & 9 & 0 & 0 & 100 \\
\hline & $\mathrm{m}^{3} / \mathrm{m}^{2}$ area & 0.35 & 0.42 & 0 & 0 & 1.36 \\
\hline \multirow{2}{*}{ Electricity use from grid } & $\mathrm{kWh} /$ person & 2100 & 504 & 0 & 1000 & 133 \\
\hline & $\mathrm{kWh} / \mathrm{m}^{2}$ area & 84 & 24 & 0 & 16 & 2 \\
\hline Electricity product & Type & CH-Label & CH-Label & - & $\mathrm{CH}$-grid & KR-Grid \\
\hline \multirow{2}{*}{$\begin{array}{c}\text { External energy demand excl. } \\
\text { electricity }\end{array}$} & $\mathrm{MJ} /$ person & 1440 & 450 & 2376 & 3177 & 0 \\
\hline & $\mathrm{MJ} / \mathrm{m}^{2}$ area & 58 & 22 & 340 & 51 & 0 \\
\hline External Energy & Type & Biogas & $\begin{array}{l}\text { District heating } \\
\text { Natural Gas }\end{array}$ & Rapeseed oil & Pellets & - \\
\hline $\begin{array}{l}\text { Application of: } \\
\text {-composting of feces }\end{array}$ & & $-\mathrm{NO}$ & $-\mathrm{NO}$ & $-\mathrm{NO}$ & -YES & $-\mathrm{NO}$ \\
\hline$-\mathrm{N}$ recycling from urine & & $-\mathrm{NO}$ & -YES & $-\mathrm{NO}$ & $-\mathrm{NO}$ & $-\mathrm{NO}$ \\
\hline -P recycling from urine & & $-\mathrm{NO}$ & -YES & $-\mathrm{NO}$ & -YES & $-\mathrm{NO}$ \\
\hline -composting of kitchen waste & & -YES & -YES & -YES & -YES & -YES \\
\hline \multirow[t]{2}{*}{ Biomass: avoided UBP } & UBP/person & 223,603 & 654 & 223,603 & 210,788 & 223,603 \\
\hline & $\mathrm{UBP} / \mathrm{m}^{2}$ area & 8944 & 31 & 32,035 & 3359 & 3032 \\
\hline
\end{tabular}


Table 10. Cont.

\begin{tabular}{|c|c|c|c|c|c|c|}
\hline Indicator & Unit & Umwelt Arena & $\begin{array}{c}\text { Forum } \\
\text { Chriesbach }\end{array}$ & $\begin{array}{c}\text { New Monte Rosa } \\
\text { Hut }\end{array}$ & $\begin{array}{c}\text { Aquamin } \\
\text { Zuchwil }\end{array}$ & $\begin{array}{c}\text { Kolon e+ Green } \\
\text { Home }\end{array}$ \\
\hline \multicolumn{7}{|l|}{ Qualitative aspects: } \\
\hline -Public transport & & -FA & -FA & -NA & -FA & -PA \\
\hline -Integration of greenery & {$[\mathrm{FA}=$ fully applies } & -PA & -PA & $-\mathrm{NA}$ & $-\mathrm{NA}$ & -FA \\
\hline -Change of use possible & $\mathrm{PA}=$ partially applies & -PA & -PA & $-\mathrm{PA}$ & -FA & -PA \\
\hline -Use of ecological materials & $\mathrm{NA}=$ does not apply $]$ & -FA & -FA & -FA & -PA & -FA \\
\hline -Grey energy of construction & & -FA & -FA & -FA & $-\mathrm{PA}$ & -FA \\
\hline -Design fits the surroundings & & -NA & -PA & -PA & -PA & -PA \\
\hline \multirow{2}{*}{ Additional Points } & Points/person & 4 & 7 & 40 & 800 & 400 \\
\hline & Points $/ \mathrm{m}^{2}$ area & 0.16 & 0.32 & 5.73 & 12.75 & 5.42 \\
\hline Total Rating Points & Points $/ \mathrm{m}^{2}$ & 19,665 & 6021 & 42,114 & 15,473 & 12,786 \\
\hline Degree of achievement & $\%$ & 90.17 & 96.99 & 81.28 & 91.86 & 93.27 \\
\hline Zero Emission Label & & YES & YES & YES & YES & YES \\
\hline
\end{tabular}

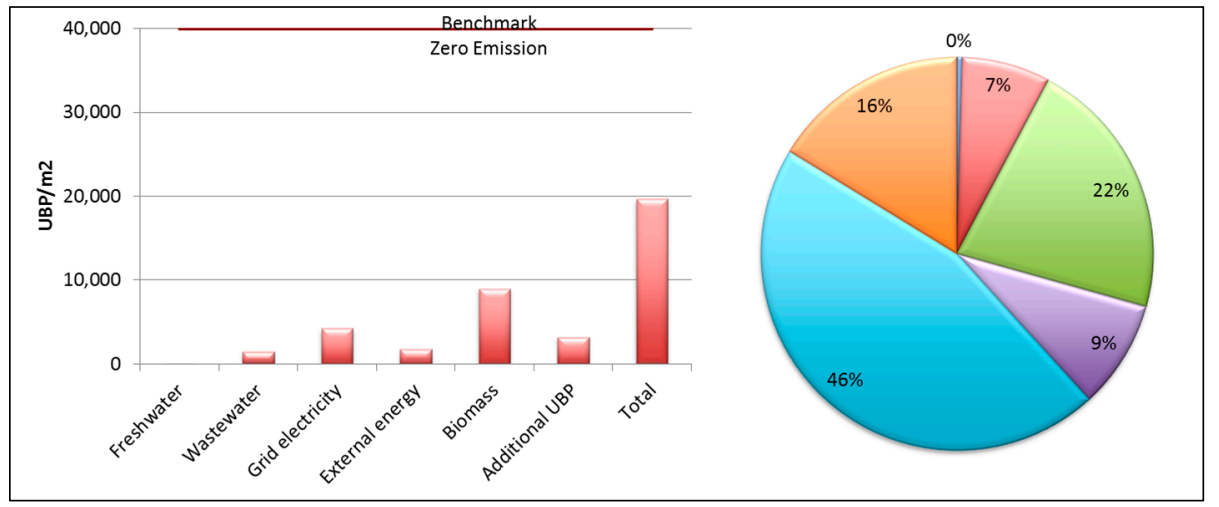

(a) Umweltarena

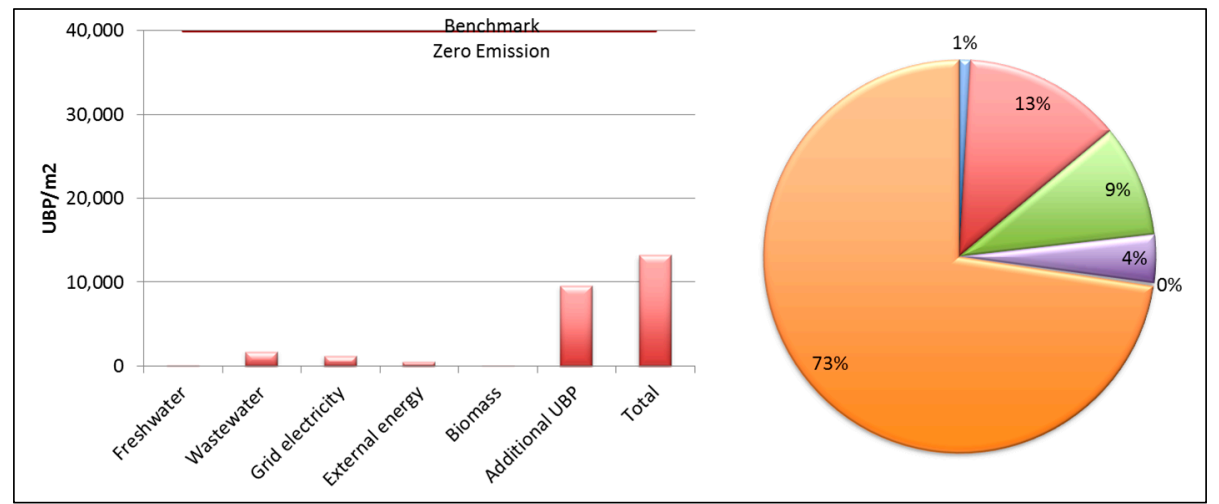

(b) Forum Chriesbach

Figure 7. Cont. 


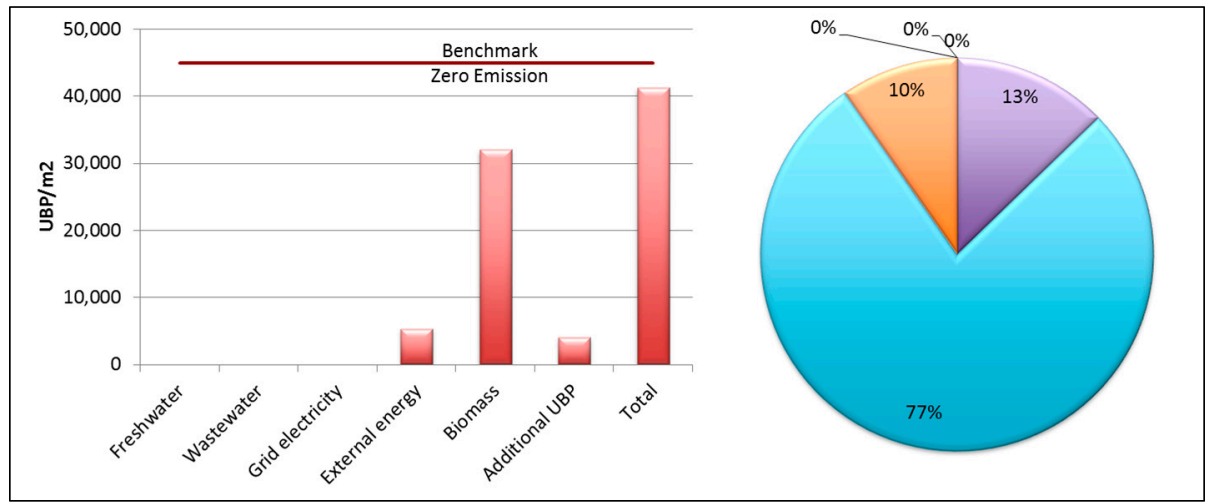

(c) Monte Rosa Hut

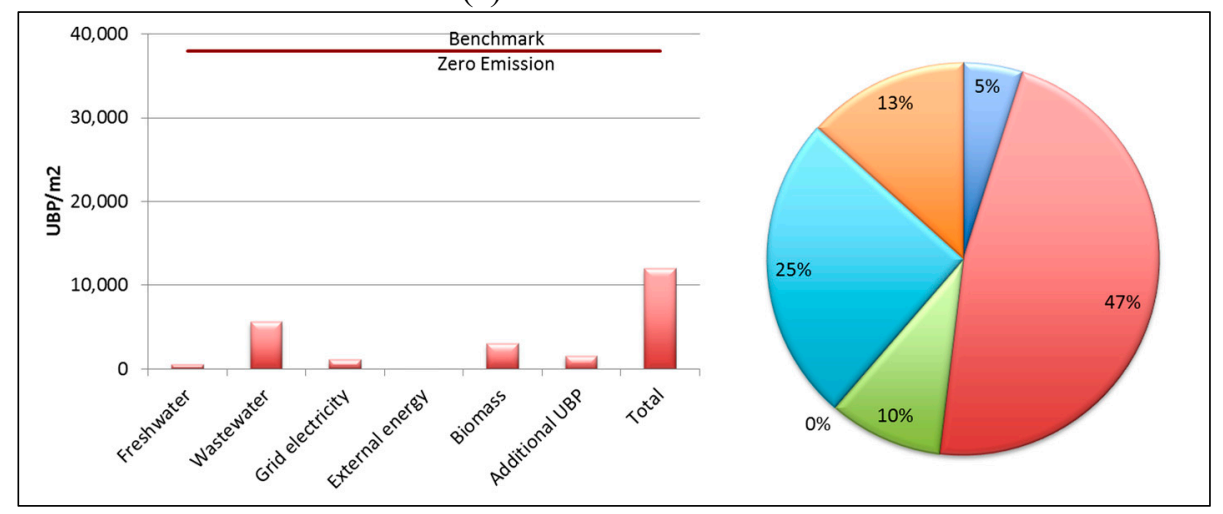

(e) Kolon e+ Green Home, South Korea

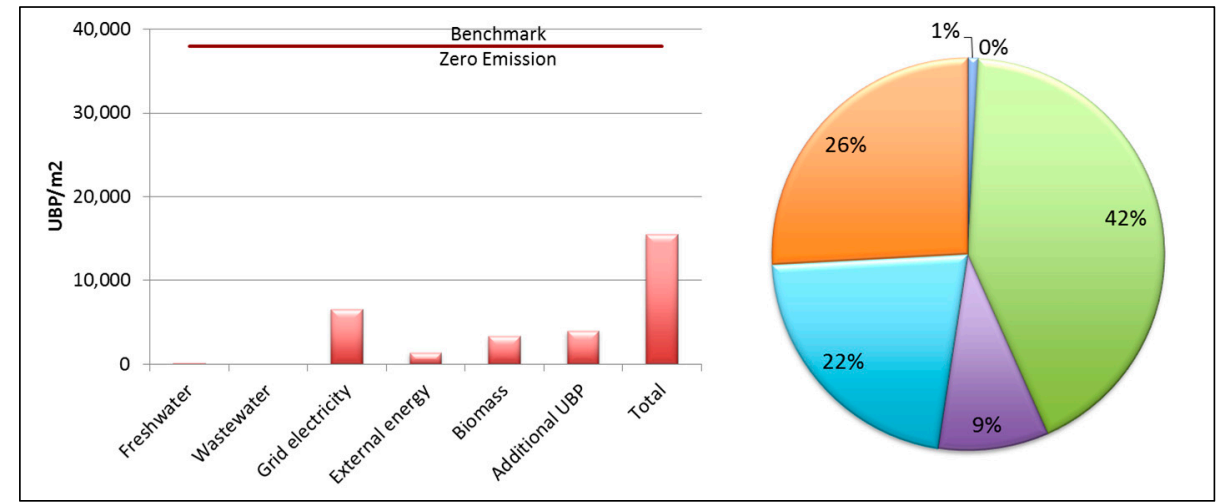

(d) Aquamin House

$\square$ Wastewater

$\square$ Grid electricity

External energy

Biomass

Additional UBP

Figure 7. Output from the Zero Emission Buildings Assessment Tool (ZEBAT) for the five examined buildings. (a) Umweltarena; (b) Forum Chriesbach; (c) Monte Rosa Hut; (d) Aquamin House; (e) Kolon e+ Green Home, South Korea. 


\section{Conclusions}

The evaluation of specific case studies with the ZEB Assessment Tool showed that the method is well adapted to the requirements of the ZEB Concept. Firstly, the tool requires a small amount of input data, which enables a simple primary assessment of a specific building. Secondly, it incorporates qualitative aspects, which are a crucial factor of the ZEB Concept. In Switzerland there is an existing assessment tool from [41] (Gebäudeenergieausweis der Kantone) called GEAK Light for the pre-evaluation for the issue of an EPC. Similar to the ZEBAT, it enables a simple primary evaluation of an existing building in $30 \mathrm{~min}$. However, GEAK Light solely covers the aspect of energy in order to improve the energetic performance of a building. The aspects of water, biomass and qualitative aspect are not covered at all. Furthermore, there is the German DGNB Label [2], which also used tools for the assessment and certification of sustainable buildings under the Label. Its strong point is that the second-generation label addresses other factors besides energy, such as sociocultural quality, functional quality, economic quality or life cycle analysis. In addition, it incorporates an approach towards the aspect of water but it lacks the evaluation of the biomass sector. Moreover, DGNB assesses many criteria and thus the process is elaborate and complex. Consequently, it is not appropriate for a basic initial assessment of case studies under the ZEB Concept. However, many of the approaches of DGNB would be interesting to integrate into the framework of ZEB regarding the construction and certification of future buildings. Similar to DGNB in Germany, in Switzerland the most common label is Minergie [1,32]. From the different Minergie certification standards, Minergie-A-Eco is probably closest to the ZEB Concept. "Minergie-A" certified buildings are "Minimum Energy Active" houses that, even more than passive houses, produce more energy than is required for their operation. "Minergie-Eco" stands for superior aspects such as use of ecological materials, grey energy or efficient use of tap water. These are a number of good approaches but other factors such as wastewater treatment or nutrient recovery are not covered in the Minergie-Eco certification system.

Beside the discussed aspects, most tools are adapted to a specific country. The transfer to other countries is usually a complex process. The ZEBAT was designed with special attention to this fact. UBP values vary for different countries and can be easily adjusted for every country. In addition, it allows for a simple comparison of different buildings since it assesses the overall performance of a building and not single technologies. Nevertheless, some factors are still missing in the ZEBAT. These include economic quality or further qualitative aspects such as noise and light emissions. In addition, in terms of energy, only end energy consumption was considered. In fact, the primary energy consumption of a building is an important factor regarding energy efficiency and overall sustainability. However, the calculation of the primary energy can be relatively complex and would have gone beyond the scope of this thesis. If more factors were integrated into the tool, it would have lost its advantage of simplicity and would have become too complex.

Furthermore, many of the benchmarks established in the tool were based on data from a limited number of case studies, mainly located in Switzerland. It should be considered, that the benchmarks could vary significantly according to the used data, especially if they stem from countries with different geographical location. The benchmarks will be further specified in future research using a higher number of case studies from different countries as well as negative examples of case studies. 
Most likely, the benchmarks will be set differently which could mean that some of the ZEB case studies will not qualify as such anymore.

Overall, the ZEBAT is well suited to easily scan ZEB Case Studies and does not omit the opportunity to include aspects of future developments and societal insights.

An in depth validation of the ZEBAT was not part of the described research. Therefore the validation of the ZEBAT will be executed in the framework of future research projects, which aim for the further development and validation of the presented ZEBAT.

\section{Acknowledgments}

The authors would like to thank Matthias Stucki and Petra Hagen Hodgson from Zurich University of Applied Sciences, Switzerland for their productive discussion and inputs. We also thank the contributors to the case studies: Walter Schmid from Umwelt Arena Spreitenbach, Thomas Lichstensteiger, Daniel Beerle and Erich Eschmann from Eawag Dübendorf, and Christian Abegglen from ERZ Zürich. Special thanks to Ji-Eun Kang from Department of Architecture, Sungkyunkwan University for procuring the data from KOLON Global about the Kolon e+ Green Home. This work was partly supported by funding received from the KORANET Joint Call on Green Technologies [42].

\section{Author Contributions}

The research project ZEBISTIS [43] was initiated by T. Schuetze. He formulated the holistic definition, on which this research was based. The idea of developing an evaluation tool was developed jointly by R. Junge and D. Bühler. D. Bühler designed, and performed the research, and wrote the paper, with inputs from T. Schuetze and R. Junge. All authors read and approved the final manuscript.

\section{Conflicts of Interest}

The authors declare no conflict of interest.

\section{References}

1. Minergie. Available online: http://www.minergie.ch (accessed on 19 February 2015).

2. DGNB System. Available online: http://www.dgnb-system.de/de/ (accessed on 19 February 2015).

3. Cerway HQE (Haute Qualité Environnemental). Available online: http://www.behqe.com (accessed on 14 December 2014).

4. Building Research Establishment's Energy Assessment Method (BREEAM). Available online: http://www.breeam.org (accessed on 19 February 2015).

5. LEED-U.S. Green Building Council. Available online: http://www.usgbc.org/leed (accessed on 19 February 2015).

6. Comprehensive Assessment System for Building Environmental Efficiency (CASBEE). Available online: http://www.ibec.or.jp/CASBEE/english/ (accessed on 14 December 2014).

7. Berardi, U. Sustainability Assessment in the Construction Sector: Rating Systems and Rated Buildings. Sustain. Dev. 2012, 20, 411-424. 
8. Voss, K.; Musall, E.; Lichtmeß, M. From Low Energy Energy Buildings to Net Zero-Energy Buildings: Status and Perspectives. J. Green Build. 2011, 6, 46-57.

9. Voss, K., Musall, E., Eds. Net Zero Energy Buildings-International Projects on Carbon Neutrality in Buildings; DETAIL: Munich, Germany, 2012. Available online: http://shop.detail.de/eu_e/netzero-energy-buildings.html (accessed on 18 April 2015)

10. Schuetze, T.; Lee, J.-W.; Lee, T.-G. Sustainable Urban (re-)Development with Building Integrated Energy, Water and Waste Systems. Sustainability 2013, 5, 1114-1127.

11. Bächtold, H.; Egli, N.; Frei, K.; Friedli, R.; Frischknecht, R.; Gugerli, H. Empfehlung Nachhaltiges Bauen-Ökobilanzen im Baubereich; KBOB: Bern, Switzerland, 2012; p. 19.

12. Bundesinstitut für Bau-, Stadt- und Raumforschung im Bundesamt für Bauwesen und Raumordnung. Energy Saving Ordinance (EnEV). Available online: http://www.bbsr-energieeinsparung.de/ EnEVPortal/EN/EnEV/enev_node.html (accessed on 17 April 2015).

13. Torcellini, P.; Pless, S.; Deru, M.; Crawley, D. Zero Energy Buildings: A Critical Look at the Definition. Available online: http://www.biomassthermal.org/programs/documents/118_ ZEBCriticalLookDefinition.pdf (accessed on 17 April 2015).

14. Sartori, I.; Napolitano, A.; Voss, K. Net zero energy buildings: A consistent definition framework. Energy Build. 2012, 48, 220-232.

15. Buehler, D. Best Practices of Zero Emission Buildings in Switzerland. Bachelor's Thesis, Zuerich University of Applied Sciences, Waedenswil, Switzerland, 1 October 2013; p. 75.

16. Bühler, D.; Junge, R.; Schuetze, T. Towards Development of a Label for Zero Emission Buildings: A Method to Evaluate Potential Zero Emission Buildings. In Proceedings of the 4th World Sustainability Forum [online], Basel, Switzerland, 1-30 November 2014; pp. 1-24.

17. Schuetze, T.; Junge, R. Zero Emission Building-Integrating Sustainable Technologies and Infrastructure Systems. Available online: http://www.zebistis.ch/index.php?option=com_content \&view $=$ article\&id=3\&Itemid=103 (accessed on 14 March 2015).

18. Frischknecht, R.; Steiner, R.; Jungbluth, N. The Ecological Scarcity Method-Eco-Factors 2006. Available online: http://www.bafu.admin.ch/publikationen/publikation/01031/index.html?lang=en (accessed on 2 August 2013).

19. Bächtold, H.; Egli, N.; Frei, K.; Friedli, R.; Frischknecht, R.; Gugerli, H.; Hischier, R.; Meile, O.; Steige, A.; Wallbaum H.; et al. Ökobilanzen im Baubereich. Available online: http://www.eco-bau.ch/resources/uploads/KBOB_Empfehlung_2009_Juli_2012.pdf (accessed on 13 August 2013).

20. Ecoinvent. Ecoinvent Center. Available online: https://ecoquery.ecoinvent.org/Account/LogOn? ReturnUrl $=\% 2 \mathrm{f}$ (accessed on 1 September 2013).

21. Hagen Hodgson, P. Zürich University of Applied Sciences, Switzerland. Personal communication, 2013.

22. Schuetze, T. Sungkyunkwan University, Korea. Personal communication, 2013.

23. Stucki, M. Dataset: Vegetable-oil-Methyl-Ester, burned in boiler $10 \mathrm{~kW}$ condensing, non-modulating/CH U. 2013, unpublished work.

24. Larsen, T.; Alder, A.; Eggen, R.; Maurer, M.; Lienert, J. Source Separation: Will We See a Paradigm Shift in Wastewater Handling? Environ. Sci. Technol. Feat. 2009, 43, 6121-6125. 
25. Bayerisches Landesamt für Umwelt. UmweltWissen: Kompostierung-hygienische Aspekte. Available online: http://www.lfu.bayern.de/umweltwissen/doc/uw_30_kompostierung_hygiene.pdf (accessed on 17 August 2013).

26. Encyclopaedia Britannica. Feces. Available online: http://www.britannica.com/EBchecked/topic/ 203293/feces (accessed on 13 August 2013).

27. Maurer, M. Aufbereitung von Urin-Flexibilität pur. Available online: http://www.eawag.ch/ medien/publ/eanews/archiv/news_63/en63d_maurer.pdf (accessed on 2 August 2013).

28. Reid, A. Preparation of liquid fertiliser stock solutions. Available online: http://www.agric.wa.gov.au/ objtwr/imported_assets/content/hort/veg/nut/liquidfert.pdf (accessed on 2 August 2013).

29. Wellinger, A.; Edelmann, W.; Schmid, M.; Wochele, J.; Angele, H. Energieproduktion aus Küchenabfällen. Available online: http://www.kompogas-bioriko.ch/pdf/Energieproduktion_aus Kuechenabfaellen.pdf (accessed on 10 March 2015).

30. Caspar, V.; Rütter-Fischbacher, U. Nachhaltiges Immobilienmanagement-Factsheets. Available online: http://www.bbl.admin.ch/kbob/00493/00495/index.html?lang=de (accessed on 30 August 2013).

31. Gugerli, H.; Frischknecht, R.; Kasser, U.; Lenzlinger, M. Merkblatt SIA 2032: Graue Energie im Fokus. Available online: http://www.brenet.ch/pdfstat_2008/06_werk_gugerli.pdf (accessed on 31 August 2013).

32. Minergie. List of buildings-SO-002-P. Available online: http://www.minergie.ch/list-of-buildings.html (accessed on 15 August 2013).

33. Schmid, W. Umwelt Arena Spreitenbach, Switzerland. Personal communication, 2013.

34. Lichstensteiger, T. EAWAG Dübendorf, Switzerland. Personal communication, 2013.

35. Eschmann, E. EAWAG Dübendorf, Switzerland. Personal communication, 2013.

36. Wentz, D. Research center in Switzerland. Available online: http://www.eawag.ch/about/ nachhaltig/fc/d1/documents/Sustainable_Construction_Chriesbach_s2.pdf (accessed on 23 July 2013).

37. Sulzer, M. Neue Monte Rosa-Hütte SAC «Die Berghütte der Zukunft». Available online: http://www.lauber-iwisa.ch/data/Ressources/1325585926-Broschuere_Monte_Rosa.pdf (accessed on 5 August 2013).

38. Fux, S.; Benz, M.; Sidler, F.; Menti, U.-P.; Plüss, I.; Gwerder, M. Monte Rosa Hütte-Integrierte Haussysteme für optimale Energie- und Stoffbewirtschaftung. Available online: http://www.bfe. admin.ch/dokumentation/energieforschung/index.html?lang=de\&publication=10999 (accessed on 2 August 2014).

39. Abegglen, C. ERZ Zürich, Switzerland. Personal communication, 2013.

40. Kang, J.-E. Sungkyunkwan University, Korea. Personal communication, 2013.

41. GEAK. Gebäudeenergieausweis der Kantone. Available online: http://www.geak.ch/StartPage. aspx (accessed on 16 August 2013).

42. Korean scientific cooperation network with the European Research Area. Available online: www.koranet.eu (accessed on 15 March 2015).

43. ZEBISTIS. Available online: www.zebistis.ch (accessed on 17 April 2015).

(C) 2015 by the authors; licensee MDPI, Basel, Switzerland. This article is an open access article distributed under the terms and conditions of the Creative Commons Attribution license (http://creativecommons.org/licenses/by/4.0/). 